\title{
'Has Anybody Heard of it?!!!': The Constable Trophy for Northern Writers and its Prize Environment
}

\author{
Will Smith ${ }^{1 *}$ \\ 1 University of Stirling, UNITED KINGDOM \\ *Corresponding Author: dr.will.smith@me.com \\ Citation: Smith, W. (2019). 'Has Anybody Heard of it?!!!': The Constable Trophy for Northern Writers and \\ its Prize Environment, Journal of Cultural Analysis and Social Change, 4(2), 13. \\ https://doi.org/10.20897/jcasc/6357
}

Published: December 11, 2019

\begin{abstract}
Book awards exist to direct prestige within an economy of cultural power. They are 'a claim to authority' over a given field (English, 2005: 51). As such, they exist 'as a solution to some claimed problem' in the wider field (Best, 2008: 13). The position of an award's given solution will often invoke other book awards, in what Claire Squires terms the 'prize environment' (Squires, 2013: 299) or English calls a 'subsidiary cultural marketplace' remarking on the 'internal logic of the awards scene' (2005: 54). This article seeks to recover the history of the Constable Trophy, a now-lapsed literary prize awarded between 1977 and 1992 to demonstrate the work of recognition performed during the award, and how the prize has a legacy within the wider UK prize environment. Working with a wide variety of sources, ranging from personal correspondence with key agents for the trophy to newspaper coverage and the novels published as a result of the prize, the article demonstrates the continuing significance of the trophy as a counter to the 'Londoncentric' publishing industry.
\end{abstract}

Keywords: constable trophy, northern writers, literary prizes, publishing, awards and prizes

\section{INTRODUCTION}

Book awards exist to direct prestige within an economy of cultural power. They are 'a claim to authority' over a given field (English, 2005: 51). As such, they exist 'as a solution to some claimed problem' in that given field, or in the field's boundaries (Best, 2008: 13). The position of an award's stated solution will often invoke other book awards, in what Claire Squires terms the 'prize environment' (Squires, 2013: 299) or what English calls a 'subsidiary cultural marketplace' revolving around the 'internal logic of the awards scene' (2005: 54). For long-running awards the solution the award offers will still need to be articulated for the award to garner attention, though in practice this dimension can become muted as a result of confidence or over-confidence in a prize's regular re-enactment appearing self-explanatory. The inception of an award is the prime moment to spell out the problem being addressed, and the solution provided. This is the moment when the inadequacy of the status quo necessitates that the prize becomes an agent of 'redistributive justice' (English, 2005: 265). This article will analyse the history of the Constable Trophy, a now-defunct literary prize which operated between 1975 and 1992, where the Londonbased publisher Constable sought to recognise, and publish, the best unpublished novel by a Northern writer. It will examine the work the Trophy did in recognising and developing literature in the North of England, creating its own networks, before moving on to consider the legacy of the Trophy within a broad environment of awards and initiatives seeking to answer the same claimed problem of geographic under-representation in the literary industry. 


\section{THE NORTH AND PUBLISHER PRIZES, PAST AND PRESENT}

In 2017, Stefan Tobler, founder of the publisher And Other Stories, announced a new Northern Book Prize, to represent and recognise the work of writers based in the North of England. Awarded for the first time in the summer of 2018, Tobler articulated the prize as a response to how 'the publishing industry is much too focused on one city' (ctd. in Wood, 2017). Perhaps uniquely, Tobler does not position the award as a definitive response but merely as one corrective. The new award's formation does not suggest the problem is new. Recognising that the problem of a London-centric publishing industry has a history, Tobler cites Muriel Spark's depiction of London-centric publishing in the 1950s in A Far Cry From Kensington. This connection is more apt than a reading of Spark's novel alone would suggest. Far Cry marked Spark's departure from her previous publisher Bodley Head to publish with another prominent London-based publisher Constable. ${ }^{1}$ Constable's company profile in British Book News notes how, despite being a smaller press than Bodley Head, Constable's marketing and publication focus on Far Cry meant an increase in Spark's sales (Menkes, 1989: 467). The very same profile documents the existence of a key initiative at Constable to respond to its position in the London-centric publishing industry, the Constable Trophy for Northern Writers. ${ }^{2}$

In Marketing Literature, Squires suggests that "Literary prizes are one of the wider agencies involved in book marketing, and are not, on the whole, initiated, let alone controlled, by publishers" (2007: 97). The Constable Trophy and the Northern Book Prize are exceptions to this trend. Both are awards instituted by publishers and both strive for a similar goal by recognising new writing from the North of England. In each case, the publisher offering the prize also offers the possibility of publication. The Constable Trophy is no longer awarded and so might appear to sit outside contemporary culture's concerns. After all, as English posits, 'the cultural field is littered with dead, cancelled, discontinued prizes' (2005: 113). Contemporary culture is more exercised by the highly shaped, 'particular kind of media event' of the award (Street, 2008: 820), whereby, as Street points out, 'prizes have become a kind of spectator sport' (2008: 819). With so many awards taking place there is little spectator interest or media value in rewatching old competitions (with the possible exception of revisiting old rounds of an ongoing prize). ${ }^{3}$ The sheer number of lapsed prizes might also be termed as a lapsed exercise of authority. But that is not to say that those littered, dead prizes do not still record traces of cultural recognition or power. Putting to one side the myriad reasons a prize may cease, the work done by a prize can still retain value and circulate long after its closure. In the Constable Trophy's case, one physical legacy of the prize is the publication history it created, with at least ten published novels from Northern writers emerging from fifteen calendar years between 1977 and 1992. Each Trophy win awarded the winner temporary custody of the physical trophy-as-object, and the etching of the winner's name on the trophy. Whilst shortlisted authors were not recorded on the physical trophy, they experienced career progression following their recognition in the running of the award. Many winners and runners up continue to identify their past involvement with the Constable Trophy in published biographical notes. The publicity and administration involved in literary prizes which may go unseen are also key in understanding their work direction prestige. The following history is a chronological integration of all those participants involved in the work of the Trophy.

\section{FOUNDING AND THE INAUGURAL WINNER}

Miles Huddleston and Joyce Bentley are both credited with initiating the Constable Trophy. Huddleston, a part of Constable's publishing team from 1964 until 1996, 'suggested' the Trophy for 'an unpublished novel by an author from the North of England' (Menkes, 1989: 467). Book prizes were, for Constable, 'a way of seeking out new talent' and were perhaps inspired by Huddleston's stint on the Arts Council Literature panel in the early 1970s (Cameron, 2009; Menkes, 1989: 467). Huddleston would have seen first hand the geographic inequalities of Arts Council distribution. Jim McGuigan's commissioned report for the Arts Council mentions the Southern skew of 1960s Arts Council Literature Panel for Great Britain funding, and goes on to show that between 1975 and 1978 the Panel awarded 83\% of its funds to writers south of Cambridge (McGuigan, 1981: 49). ${ }^{4}$ McGuigan also points

\footnotetext{
${ }^{1}$ Menkes reports Spark's move from Bodley Head to Constable triggering an increase in sales 'to 16,000 from the mere 6,000 for her previous novel' (1989: 467).

${ }^{2}$ In the same British Book News profile, Menkes outlines three book prizes which Constable was using to find new voices and unpublished manuscripts; in each case the author received a cash prize and an advance on eventual publication with Constable. The prizes run by Constable were firstly the Scottish Constable Trophy, in conjunction with the Association of Scottish Writers, secondly a prize with 'the late lamented Fiction magazine' and thirdly the Constable Trophy, focusing on writers based in the North of England.

${ }^{3}$ The documentary 'Barneys, Books and Bust Ups: 50 Years of the Booker Prize' was broadcast on BBC Four on $15^{\text {th }}$ October 2018 to mark the $50^{\text {th }}$ annual ceremony of the Man Booker Prize (The Man Booker Prize, 2018).

45 grants were received in the North of England from 117 awarded, located in Leeds, Manchester, Newcastle and Hull (twice) (McGuigan, 1981: 49).
} 
to the literature panel's working mechanisms as supporting closed networks and coteries, with panel members endorsing their peers and often receiving funding themselves when not on the panel: 'Since 1966 sixteen individuals have received grants either before or after serving on the Panel [made up of 20 people]' (1981: 46). Constable's funds and offer of publication would have intervened where, unless you happened to be Basil Bunting (in 1966 Bunting in Newcastle was the sole recipient north of London), there was little hope of public support.

In the period when the Constable Trophy was established regional arts boards did spend money on contemporary literature but it was small by comparison, and tended to encourage tours of established writers or limited numbers of writer-in-residence schemes. Emulating the earlier founding of the Constable Trophy for Scottish Writers in 1972, which worked with the Scottish Association of Writers, the Constable Trophy for Northern Writers was established to recognise work by 'members of writers circles in the six northern counties' (Benson, The Underlings, inside flap of dust jacket). ${ }^{5}$ Joyce Bentley is named in a brief biography in The Writers Directory as 'founder and secretary' of the award 'from 1975 until 1983' (Ferrara, 1997: 112). A creative writing lecturer in Blackburn, and later in life a lecturer for Open University, Bentley wrote a number of novels and works of non-fiction that were widely reviewed. Whilst there appear to be no archives of Bentley's work, her biography hints at significant literary labour, having worked as a freelance writer from 1958 and so Bentley would have been well-placed to anchor the award's interests in the North on behalf of the London publisher.

Some of the solutions public funding bodies found to London-centrism in this period involved supporting organisations rather than individual writers. A key recipient of such funding was The New Fiction Society (NFS) founded within The National Book League (now Book Trust) in 1974. NFS selected and disseminated discounted new fiction titles on a book club model. ${ }^{6}$ John Sutherland praises the society as 'one of the most imaginative schemes of patronage for the novel ever devised' (Sutherland, 1978: 143), but qualifies this praise by remarking on its cost and narrow membership. In Sutherland's words, 'it would have been cheaper to buy the novels at full price from a bookshop and give them away to passers-by at Piccadilly' (1978: 145-6). Constable's working method would have been close to the NFS scheme's goal - promoting new fiction - but with considerably cheaper overheads, since they would publish Trophy-winning works 'in house'. First hand experience of the NFS's demise would have been available at Constable, as the NFS's former manager, Yvette Evans-Foster, became publicity manager at Constable, working directly on the Constable Trophy.

Given the lack of funding or attention for Northern writing, to receive the Constable Trophy constituted a significant intervention in a writer's life. Coverage in the Newcastle Journal shows what the publication of The Underlings (1977) meant for the first Trophy winner, Barbara Benson (Mortimer, 1977: 10). Interviewed by Peter Mortimer, Benson is presented as being in a stronger position for public arts funding because of the Trophy, 'with publication she has some hopes of obtaining an Arts Council Grant, an opportunity to buy time' (1977: 10). Moreover, the occasion of the novel's publication is framed in highly gendered terms, with a developing writing career seen as fulfilling a desire which had been frustrated by family life and a teaching career, and with Mortimer emphasising Benson's 'literary star blazing relatively late' (1977: 10). ${ }^{7}$ The article fills in some more details of the trophy's early history, mentioning that the news of the Constable Trophy 'was circulated to Northern writers' circles' and that Benson participated in such writers' circles being 'a founder member of "Workshop '74" in Durham' (Mortimer, 1977: 10), of which Benson was secretary in 1974 (Anthony, 1974: 7). The twenty-five founding North East-based writers 'range from absolute beginners to published authors. Some have had work published in magazines and colour supplements and broadcast on programmes including Woman's Hour and Northern Drift' (Anthony, 1974: 7).

The Underlings' subject matter itself mirrors the prize's aims. A drama revolving around a Northern woman's recollections of working in the London-centric publishing industry in the 1950s, the novel foreshadows Muriel Spark's work in the same vein eight-years later. Benson went on to gain further national acclaim, winning the 1977 Authors' Club First Novel Award for 'most promising first novel' (Wecksler, 1980: 419). The material Author's Club recognition comprised of 'a silver-mounted and inscribed quill, presented to the winner at a House Dinner in the Club' (Cassell's Directory, 1973: 425). ${ }^{8}$ For the first Trophy winner to accrue additional honours within a wider national frame of reference reflects well on both author and the Constable Trophy.

\footnotetext{
${ }^{5}$ Established in 1972, the Constable Trophy for Scottish Writers was 'suggested' to Constable by novelist Hugh C. Rae. The prize has been awarded annually since 1972 and is still in operation, retaining the Constable name whilst having no connection with the publisher or offer of publication. The Trophy is also known as the Constable Stag, as the award itself is a silver stag trophy. Some accidents have befallen the trophy-as-object over the years: 'In 2009 the winner of the Constable Trophy, Alan MacGlas, paid at his own expense to have the antlers properly restored and now it has regained it's full magnificent rutting status.' (Personal Correspondence with Marc Sherland on behalf of The Federation of Writers, Scotland)

${ }^{6}$ A similar process operates in the better known, and still operating, Poetry Book Society, which distributes the choices of expert poetjudges to subscribing members, four times a year.

${ }^{7}$ Whilst she did not wish to share her age at the time of the interview, it seems useful to highlight now that she was 51 when The Underlings was published.

${ }^{8}$ In 1954, when the club instituted the award, it was initially for 'the most promising first novel by a male author published in the U.K' (Cassell's, 1973: 425) It was in 1967 that 'women authors' first became eligible.
} 


\section{ADMINISTRATION AND TRANSITION}

The records of the Trophy briefly run thin. Three winners are recorded, Beth Pickup (1978), Angus Macpherson (1979) and Mary Ellis (1981), but the only source for these at present is the trophy-as-object, still retained by its final winner, Graeme Rigby. Doubtless, there would have been some newspaper coverage local to the winners of Trophy, but without wider digitisation of regional newspapers it has proven difficult to uncover. Another administrator from this period, Elizabeth Battrick, is identified in pleas for entrants to the Constable Trophy, printed in a 1978 issue of ArtsPack: The Magazine of the Mid-Pennine Association for the Arts (ArtsPack, p. 18), and the next year's award in 1979 in a poetry zine, The Chair.

NORTHERN WRITERS are invited to take part in a new competition for a full-length book, fiction or non-fiction of not more than 80,000 words that has not previously been submitted to any publisher. Closing date is 31 March, 1979; the winner will be awarded the Constable Trophy and the winning manuscript considered for national publication. Rules and further details from Mrs E. M. Battrick, Association of Northern Writers, The Wood Farm, Winster, Windermere, Cumbria LA23 3NY. (The Chair, 1978)

This is the only mention of non-fiction alongside the Trophy I have traced. Also, Battrick is listed as a representative of the Association of Northern Writers, an organisation which can only be cross-referenced on the physical object of the trophy where the engraving reads 'The Constable Trophy for the Association of Northern Writers'. Battrick is noted for her writings on Beatrix Potter, the National Trust in Lakeland and other regional topics but also appears to have left no archival holdings that might frame her own involvement with the Trophy. ${ }^{9}$ Whilst there are some hopes that the winners' experiences might still be traceable, given the impact of the prize on their writing lives, the subsequent award administrator, Tim Brassell who took over work on the prize in 1982, recalls, 'my memory is that few (if any) winners were ever published' (Personal Correspondence). Assuming this to be the case, the absence of published works (broadly more highly regarded than unpublished works) stemming from an underrepresented regional background would have limited the media interest in the 'spectator sport' of the award. Without publication there would also be no monetary figure to announce, as there would be no advance on the published book's royalties.

Brassell's involvement with the prize began when it underwent a shift in structure and eligibility. In 1982, the Constable Trophy is listed in Awards, Honors and Prizes alongside two other funding initiatives administered by the Regional Arts Association, Northern Arts. ${ }^{10}$ The shift from Bentley and Battrick's term (1977-1983) to Northern Arts administration meant the chance to reperform a founding moment as a media event. Speaking at the time Brassell, as both Northern Arts' Literature Officer and Press and Publicity Officer, restated the problem and solution of the Constable Trophy: "London so dominates our literary life that the North often feels forgotten. We hope Northern writers will feel a little more enfranchised as a result of this competition" (ctd. in Isaacs, 1983: 10). This amplification of the Trophy's intention is underscored by the altered description of it in Awards, Honors and Prizes:

To recognize an author in the North of England for the best unpublished novel of the year. A monetary award of $f_{2}, 000$ and a minimum of $£ 1,000$ in advance on acceptance for publication by Constable and Company. Co-sponsored by Constable and Company, Northern Arts, North West Arts, Yorkshire Arts, Lincs and Humberside Arts, and Merseyside Arts (Wasserman and McLean, 1982: 465).

The departure here is not only spatial, from the six Northern counties to a much broader conception of the North, but also away from partnering with writers' circles, towards a collective of established Regional Arts Associations (RAAs). The need for public funds to be invested in the regions was highlighted not only by the Arts Council's own commissioned research, reflected by McGuigan's report on the Southern focus of pre-1977 awards, but in the broader strategy document 'Glory of the Garden' published by the Arts Council of Great Britain in 1984. 'Glory of the Garden' set out a template for devolving decision-making power in investment towards RAAs, to attempt to reach a broader geographic spread. However, for the Constable Trophy to engage with this system it entailed co-ordinating around established Arts Council boundaries, encountering the on-going question of where the North of England begins and ends.

\footnotetext{
${ }^{9}$ See Battrick's A Lakeland Summer (Cicerone, 1979), The Real World of Beatrix Potter (Jarrold, 1986), Guardian of the Lakes: A History of the National Trust in the Lake District from 1946 (Westmorland Gazette, 1987), and The Most Active Volcano in Europe: Canon Hardwricke Drummond Rawnsley (National Trust, 1995).

10 The Northern Arts Literary Fellowship 'of $£, 10,000$ for a period of two academic years at the University of Durham and Newcastle Upon Tyne' and the Northern Arts Writers' Awards 'to recognize established authors resident in the Northern Arts area on the basis of literary merit and financial need. Monetary awards are presented annually' (Wasserman and McLean, 1982: 465).
} 
Reflecting on his first year of administration, Brassell noted in 1984 that 'expanding the competition to take in the rest of the North of England had allowed prize money to be offered for the first time, increased entries tenfold and created a new contest of considerable value to novelists' (ctd. in Southwell, 1984: 8). Brassell's recollection from the present is more revealing in understanding the administrative work Northern Arts took on as lead organiser. Realising that the Trophy was failing in its goal to produce published work for Constable, Brassell responded to writers' concerns:

So in 1983 having learnt from disappointed local writers that Constable were thinking hard about any future support, I approached the other Northern RAAs (Yorkshire Arts, North West Arts and Lincolnshire \& Humberside Arts) with the idea of joining forces with us to expand the competition into something with a much higher profile, a cash prize carrot (we settled on $f, 2000$, with $f, 500$ from each RAA) and hopefully rather more productive outcomes. They readily agreed in principle and I therefore went to London and met with Ben Glazebrook, Constable's MD, who was very pleased with the plan. I'm fairly sure this included offering that initial filleting of entries would be carried out by well-qualified members of our four Associations' Literature Panels (writers, county librarians, academics etc.) so as to present Constable with a manageable shortlist! All administration was coordinated from our office at Northern Arts, since we had taken the original initiative and I was happy to continue to take the lead on it, often reminded by RAA colleagues that Northern Arts had more resources than they did (which was generally true!) (Personal Correspondence).

This pooling of resources meant that each RAA would be promoting the prize and together reaching across a combination of the North's local media more effectively. Notices regarding the prize after this relaunch often appeared in the Newcastle Journal, the Northern Echo, the Liverpool Echo and the Yorkshire Post.

\section{TROPHY WINNERS REAPPEAR IN PRINT}

In 1983 the award's own requirement for Northern residence was stretched. Malcolm Lynch was living in Teignmouth in Devon, working as an editor on the Teignmouth Post when he won the Trophy. But Lynch was better known to many for his role in Northern cultural production, as 'script writer on Coronation Street, Crossroads and Emmerdale Farm' (The Spectator, 1985) before a geographic leap to become editor of popular BBC radio programme The Archers. His winning submission had a strong Northern basis and there is every possibility that he qualified for entry through a Northern writing circle in the last year where this affiliation would be necessary. Despite his status, no major newspaper publicity recorded the win itself. However, in 1985, Nicholas Shakespeare remarked on the win whilst reviewing the published novel in The Times, describing the Constable Trophy as 'a north of England award for the best part of an unpublished manuscript' (Shakespeare, 1985: 11). This might have been provided as context for what is a lukewarm review. Shakespeare suggests Lynch 'would have written it better as an autobiography' (1985: 11), perhaps proving that London-based recognition could also reassert London-centric tastes, and that a publication's national and global reach still takes part in the system it seeks to counter. As with Benson's win, it was two years between Lynch's win and publication of the novel, hinting at a conscious period of editorial work with Constable. Lynch benefited from his connection with Constable, as they went on to publish his second novel, They Fly Forgotten (1987), revisiting the Manchester-setting of The Streets of Ancoats. Constable also benefitted from the association. Robin Baird-Smith, then editorial director of Constable, recalls that The Streets of Ancoats 'was a great commercial success - a triumph of publishing set in a locality - as it seemed that anyone in Ancoats who could read bought the book' (Personal Correspondence).

Publicised in newspapers, magazines and television, winner and runner up in 1984's Trophy were both published by Constable. This made significant differences in the careers of the writers selected. Denise Robertson, 'former agony aunt for Metro Radio' (Southwell, 1984: 8) won the Trophy with The Land of Lost Content and went on to publish a number of subsequent titles with Constable whilst finding fame on television as the agony aunt for ITV's This Morning from 1988. In an excerpt from her autobiography, Robertson recalls "When I submitted a novel I had written about a young coal miner's widow for the prestigious Constable trophy, I won" (Robertson, 2006). The notion that the Trophy is prestigious as articulated by a winner might seem self-serving, but it is also a measure of esteem for the work of the award. In such circumstances, an award is buoyed by the faith in the solution it is providing to a problem, and how this has a tangible effect. Robertson's first novel was a commercial success, being followed by two sequels in what became The Belgate Trilogy. A collected paperback was published by Penguin in association with Constable in 1988. Fiction Magazine, Constable's sometimes partner in a separate short story award, ran a small article on the simultaneous publication of Robertson, runner up Barbara Gamble and Lynch in the context of 'Constable prize-winners!', outlining their media appearances as a result of the Trophy. 
Styled by Fiction Magazine as a production of the 'Northern Arts Council' the extent to which the award is a media event is evident:

BBC TV's 'Look North' featured both Denise Robertson and Barbara Gamble -- a film of Denise made at home and on location, and an interview with Barbara. There was also a round of interviews with north-eastern radio stations and of features in local papers, for both of them. Malcolm Lynch wrote a 6minute film-script for Granada TV's 'Reports', and was interviewed by BBC Radio Manchester and Radio Hallam (Fiction, 1985: 56).

Presumably the connections with RAAs meant an enhanced understanding of how to circulate notions of success and prestige, and so to perpetuate ideas of the Trophy as a media event. The archived media coverage expands upon the published works, leaving social reflection that underscores the Trophy as a solution to the publishing world's inequalities.

After the RAA takeover of Trophy administration, more details about the prize's operation became public, and were deployed as a way of attracting entrants. Key to this effort was the regular listing of judges who would be presiding over the prize. These judges are, in English's terms, a strong 'source of symbolic capital' for the prize (2005: 123). In 1983, the list of judges included Pat Barker, Adrian Henri, Henry Livings, Maureen Lawrence and Stephen Benetar (Isaacs, 1983). The name Pat Barker here has the most resonance today, as she went on to win the Booker Prize in 1995. Barker's judging work for the Constable Trophy came just after publication of her lauded debut novel, Union Street (1982). Winning the Fawcett Society Book Prize, Barker's work would have represented the aims of the Trophy by firmly countering dominant literary biases by representing working-class women in the North. Adrian Henri would also have been a household name nationally, from his work alongside Roger McGough and Brian Patten in the bestselling poetry anthology The Mersey Sound (1967), from frequent public performance, and being well connected with networks of artists and writers in Liverpool. Henri's championing of Liverpool as a place of creativity would have added further substance to the Trophy's aims. Subsequent years saw authors with connections to the North, and with prestige gained from other prizes take up roles as judges, e.g. Barry Unsworth, Jane Rogers and Elizabeth North. There was clearly a desire to maintain strong Northern representation, and so writers for television, film and stage with recognisable Northern standpoints were also involved. The 1986 panel included 'Brookside Writer Alan McDonald' and 'Sid Chaplin of Close the Coalhouse Door fame' (Isaacs, 1985: 6) highlighting connections with the then popular Northern drama and Alan Plater's play based on Chaplin's stories of coal mining in County Durham. Chaplin's career as a novelist and contributor to The Guardian was premised on representing the North-East and his cultural capital associated with the Trophy would have spoken to a local demographic with few connections to London. ${ }^{11}$ Unfortunately Chaplin died in January 1986, before he was able to fulfil judging duties. Later juries included previous winners alongside other noted Northern writers, e.g. Jimmy McGovern, Robert Edric and Elizabeth Baines. The inclusion of previous winners as jurors could have been a handy continuation of association, but also suggests the aims of the prize were being met, as writers such as Robertson continued to be published and to gain a wider readership, ascending to a position which attracted the necessary cultural capital needed to be a judge.

In 1985, Edith Breahm, writing under the name Edith French, won the Constable Trophy and Connie and Ann was published by Constable in 1986. The novel was described in a publication announcement in the literary magazine Stand as 'a lively, fast-paced saga of a north country family in the '30s' (1986: 19). The same announcement mentions Constable's simultaneous publication of the runner-up in 1985, Gerald Phillipson's $A$ Place Called Adullam. Whilst there is no trace of any subsequent writing by French, Phillipson had at least one other award-winning story published. ${ }^{12}$ In 1986, Gerald H. Morris, won the Trophy and Doves and Silk. Handkerchiefs was published by Constable in 1987. Kirsty Milne reviewed Doves for The Guardian, not mentioning the Trophy, but describing the novel as 'somewhere between D.H. Lawrence and "Cold Comfort Farm"... home-produced—and Northern-magic realism' (Milne, 1987). Peter Preston was unable to resist a slight joke at the subject matter in his review, noting 'the author avoids what might be called the pitfalls of the mining novel, tunnelling a skilful passage between Lawrentian earnestness and the traditional absurdities of the genre' (Preston, 1987). Morris followed the novel with two subsequent books Grandmother, Grandmother, Come and See (Constable, 1989) and The Brightside Dinosaur (Constable, 1991). The three are a trilogy following the Leeds-based Brightside Family, beginning in a West Yorkshire mining town and tracking changes over the course of the next two hundred years. As with Robertson, Penguin collected the trilogy in one volume for paperback publication in 1992. In both cases, the continuation and eventual collection of work initiated by the Trophy are an indication of its impact. Yet, in both

\footnotetext{
11 As DJ Taylor notes “To read even a few pages of Chaplin's work is to be plunged immediately into a fictional equivalent of the workingclass landscapes described in Richard Hoggart's The Uses of Literacy (1957)" (Taylor, 2005).

12 A short story, 'Henry and Dorthie', appeared in Stand in 1989. Adapted by Phillipson as a play, 'Henry and Dorthie' came runner-up in a BBC World Service playwriting competition in 1993 and was subsequently broadcast on the radio by BBC World Service. The original short story 'Henry and Dorthie' went on to be reprinted in Robin Baird-Smith's annual Constable anthology, Winter's Tales in 1994.
} 
the 1985 and 1986 prizes, winners appear not to have been as well-advertised. A Newcastle Journal article advertising the 1990 prize hints at why the traces of the Trophy as media event are less prominent in these years, listing 'other Constable winners ... Edith French (1985, North Yorkshire) for Connie and Ann, and Gerald Morris (1986, Leeds) for Doves and Silk Hankerchiefs [sic]' (Jones, 1989). In these listings, the place of affiliation seems to matter as much as the writer or novel. Following Best's recognition that in certain awards, 'the recipient's importance may even be downplayed, while the group from which the winner comes is exalted' (2008: 12), there seems to be a slippage here where the part of the North the author belongs to becomes of equal importance. Considering the coalition of RAAs participating, the Trophy's idea of North is a collaborative imaginary, but at another level, those RAAs retain operational independence to support artistic labour in their own particular geographies. The shifting focus on where in the North an author comes from could have led to a differing, localised geography to the Trophy as media event, but if this did not correspond to Northern Arts' own boundaries, as the lead administrating RAA, then there may well have been less organisation or resources to promote the win. Presumably reflecting on the considerable resources and organisation required, the Constable became a biennial prize after 1986.

The annual reports of the Northern Arts Association attest to the RAA's involvement with the prize from 1984 onwards, but the Trophy shifts from a project discussed by officers to a budget line. Public record of these reports cease in 1987/88. January 1988 saw a second landmark funding review conducted by Richard Wilding 'to examine the working relationship between the Arts Council and the Regional Arts Associations' (Rittner, 1989: 5). Outlining the context for this review, Rittner, the Arts Council Secretary General notes 'the relationship between the Council and the RAAs has always been spiced with a creative tension verging on rivalry' (1989: 5). The RAAs commitments to keeping the Trophy going could appear weakened by the diminishing records, but the way the Trophy was seen might also account for its shift in documentation. Jenny Attala, the literature officer who succeeded Brassell at Northern Arts, recalls that the Trophy was impressive because the partnership of RAAs:

would directly benefit talented people by bringing them to the attention of e.g. publishers who might not otherwise have considered or been aware of the work. I was impressed by the ethos which organised competitive schemes and rewarded quality work, offering support to writers to produce work and initiating partnerships to promote it more widely. The Constable Trophy was an excellent example of this in literature and there were other initiatives in collaboration with Tyne Tees Television and BBC Cumbria to offer competitive opportunities to scriptwriters and directors from the region to make work which would be broadcast. (Personal Correspondence)

Situating the Constable Trophy in a wider field of collaborative industry initiatives is persuasive, but reduces the sense of the Trophy as an exceptional event-based strategy. In a policy framework, or from an administrative outlook, industrial partnership is an important way to outline the professional development work the Trophy is doing, but lacks the notion of spectacle that attracts public attention to the showbusiness of prizegiving. Encouraging public interest in the completion of a 'competitive scheme' seems less likely to draw the crowds.

\section{THE PEAK OF THE CONSTABLE TROPHY'S PUBLIC PROFILE}

The 1988 winner of the Constable Trophy created the greatest amount of headlines and went on to be a bestseller for Constable. Paul Sayer's The Comforts of Madness (1988) is a significant Trophy winner in many ways, but most surprisingly came to be written because Sayer used the existence of the Trophy as an incentive. Sayer recalls: "My first entry, in 1986, was the kind of weak, partly-autobiographical novel that many writers begin with, though it did make the longlist - the last twenty-four of a hundred and forty-odd entries. It didn't win ... but it was encouragement enough for the Constable Trophy to be my first port of call with my next effort" (Personal Correspondence). Upon winning the prize, Sayer recalls the Trophy and the award ceremony:

[A] silver tankard - indeed the 'Trophy' itself - with my name inscribed on it alongside the previous winners, plus a $£ 1000$ prize from Yorkshire Arts, and a further $£ 1000$ advance from Constable, was presented to me at a sweet little gathering at Bradford Arts Centre, presided over by Constable's noted editor Robin Baird-Smith, with whom I was to publish my next three novels. It was covered by the Bradford Telegraph and Argus and maybe one or two other regional papers. (Personal Correspondence)

The local coverage of this event underplays what would happen following the award. Sayer's The Comforts of Madness was reviewed on publication by Mark Casserley in the Times Literary Supplement, with the Trophy win mentioned at the head of the article (Casserley, 1988). Whilst Casserley's response is mixed the novel attracted much greater attention after it went on in the autumn of 1988 to be shortlisted for, and then to win the Whitbread 
Award category for Best First Novel. ${ }^{13}$ The winner of this category had never previously won the overall Whitbread Award for Book of the Year. The cross-genre final shortlist included poet Peter Porter, biographer AN Wilson, novelist Salman Rushdie and children's writer Judy Allen. In January 1989, a judging panel including then-Home Secretary Douglas Hurd, chose Sayer's novel as the book of the year, conferring on it the $£ 20,000$ prize. Two newspapers ran with headlines of 'Rushdie Pipped At the Post' framing Sayer's Whitbread win as 'an unexpected victory' against the favourite Salman Rushdie (Daily Mail, 1989; de Jongh, 1989) or more strongly, as a kind of theft. Robin Young wrote on the front page of The Times that "A first novel by a psychiatric nurse last night stole Britain's most valuable literary prize from the year's most hyped novel, The Satanic Verses by Salman Rushdie" (Young, 1989). How Sayer came to be published is explained by Young as 'a competition in the North for best unpublished novel' but the Constable Trophy is not explicitly credited. In a follow-up interview with Sayer in The Guardian, John Vidal notes:

Although it won the little-known Constable trophy - a biannual competition for the best unpublished novel in the north of England, and $£_{2}, 000$ (half from northern regional arts councils) - Constable only printed 2,000 copies. Today they are chirrupping over champagne and talking of reprints and big coin... (Vidal, 1989)

For Constable, the physical book, carrying the mark of the Trophy win on the cover, saw a huge spike in sales following the Whitbread prize win. Menkes notes that 'before the Whitbread announcement it had sold 1500 copies, three months later sales had increased tenfold to 15,000 in hardback and a large number of foreign rights sales had been made' (1989: 467).

The Comforts of Madness is listed in bestseller charts throughout 1989 and received very warm reviews when Sceptre published it in paperback in August 1989. Brian Morton credits both award wins in praising the book: “This, Sayer's first novel, won him both the Constable Trophy and the 1988 Whitbread Book of the Year award. It is a remarkable technical tour de force, a luminous first person insight" (Morton, 1989). Speaking now, having published four novels with Constable and two with Bloomsbury, Sayer relates that the Trophy was an incredibly important award:

It was a true game-changer. The chances of a completely unknown writer getting a book published, particularly someone from outside London, were said to be one-in-a-thousand at that time - no internet then, of course - and I had circumvented the iron walls of the literary establishment and made it into their ranks. (Personal Correspondence)

The conversion of the prestige of the Trophy into another accolade, and a regular writing career, must make this the most successful and influential year in the Trophy's history. The assumed function of the Trophy to talent spot is remarked upon in a review of a later novel of Sayer's, where Sutherland mentions the Constable and Whitbread as evidence of literary pedigree. ${ }^{14}$ Considering two other upcoming writers (Paul Watkins and Louis de Bernieres) who have been recognised by awards, Sutherland concludes 'the literary prize system is working rather well in Britain' (1992: 18).

\section{THE LAST YEARS OF THE CONSTABLE TROPHY}

In 1990, the actress Prunella Pulsford won the Constable Trophy. Lee's Ghost, Pulsford's winning novel, was published by Constable in the same year. The inside flap of the dustjacket reiterates the book cover's message that Lee's Ghost is the Trophy winner, expanding to comment that: 'the purpose of the Constable Trophy is to discover new talent - here is a writer with a truly original voice' (Pulsford, 1990). Omitting mention of the Trophy's geography, the copy underlines the core purpose that the award serves for Constable in finding and promoting new talent. In framing the Trophy this way, the consumer's perception of the Northernness of Constable's search is diminished. This may have something to do with the setting of the novel. This presentation of the book is replicated in Jo-Ann Goodwin's Times Literary Supplement review, which opens: "Lee's Ghost, the winner of the 1990 Constable Trophy for Fiction, is set in a small south coast seaside town" (Goodwin, 1990). If the publication of a Trophy winner is still tailored to the book rather than the author, it would seem Constable presumed the audience for a novel set in Southern England might be distracted by prompts of Northern branding. However, the need to adapt the branding for publication inevitably alters one of the few public-facing avenues for circulating notions of the Trophy too. Another positive review in The Times does not mention the Trophy win (Nicholson, 1990), again

\footnotetext{
${ }^{13}$ In a stroke of synchronicity, in 2019 I am a Costa Book Awards judge for this same category - the current incarnation of the Whitbread. ${ }^{14}$ Sutherland also mentions Sayer's nomination for another award which subsequent research has been unable to corroborate. Sayer's association with 'Northern Male personality of the year' is thus confined to this award-saturated review.
} 
limiting reader recognition of the Trophy in connection with Pulsford, and omitting mention of the Trophy from a key part of its potential media event. Although discourses of review remain outside the award's control, they are a key terrain for award signalling. If the Trophy meant little to a book reviewer in 1990, this would be surprising given Sayer's supersignification as the previous winner. In turn, a reviewer's engagement with the now biennial Trophy may have lapsed in comparison with other annual awards cycles. Retrospective reference to Pulsford's Trophy win is limited given that Pulsford has not had another novel published subsequent to Lee's Ghost.

In 1992, the Trophy jury included Robert Edric, Christopher Burn and the 1988 winner Paul Sayer. Sayer's recollection of judging is framed by a discontent with an all-male jury, but points to a wealth of entries:

Our dealings with each other were all very cordial, though I do remember bemoaning the fact that it was an all-male panel. We only met once, I think, which was to come up with a winner and a runner-up. Some of the hundred-and-odd entries were half-baked and mediocre, as is usual in these things, and, as is also typical, a large number were perfectly decent efforts simply lacking that extra spark to make them stand out from the crowd. The winner was a riser from the start, and a fairly obvious choice after we had gone through the rest of the more promising entries (Personal correspondence).

Graeme Rigby was the eventual winner of the Trophy, and in 1993 Constable published The Black Cook's Historian. An interview in the Newcastle Journal outlined Rigby's path to writing and further emphasised the Northern nature of the Trophy (Sherwood, 1993). James Sherwood noted that "The winner is not guaranteed publication, but Graeme's work not only brought publication but also an agent and an option held by Constable to publish his next novel. Graeme received the trophy, plus a cheque for $f, 2,000$, at Durham Art Gallery yesterday from the folk singer Maddy Prior" (Sherwood, 1993). Perhaps Prior was chosen as a resonant figure, being a northern singer who had made a large impression on the nation, but no national media appear to have covered the ceremony itself. The novel gained many reviews, was discussed on Radio 4's 'Kaleidoscope' (The Times, 1993), and the Trophy win was mentioned in TJ Binyon's review in The Times Literary Supplement:

The synopsis promises a stirring story, and appetite is further whetted by the information that the novel is the winner of the 1992 Constable Trophy for Fiction. (Not the Prix Goncourt perhaps, but surely of some significance) (Binyon, 1993).

The Trophy itself is clearly not familiar or conveying any particular kind of prestige, but Binyon's interest is piqued by the idea of the award. The notion that it carries 'some significance' attests to a qualified notion of meaning, and to its relative obscurity. No further award of the Trophy means that media coverage ceases, and reference retreats to footnotes in biographies. By the mid 1990s, Robin Baird-Smith and Miles Huddleston had left Constable, and by 1999, Ben Glazebrook had sold the publisher to fellow independent Robinson Publishing. ${ }^{15}$

\section{THE PRIZE ENVIRONMENT}

The physical trophy, well-polished, still lives on Graeme Rigby's mantelpiece (Figure 1). The bare list of names on the well-polished trophy erases the composite nature of the award's benefit. The jurors and runners up experienced their own successes through being part of the process, producing work for the Trophy that went on to be submitted and recognised by alternative awards and publishers. Beyond this, and the winners stories related as part of the history above, the legacy of the Trophy is present in an evolving prize environment.

The first reference I found to the Constable Trophy was in the archives of another Northern book prize, the Portico Prize, due to be awarded again in January 2020 following a four-year hiatus. ${ }^{16}$ The Portico Library, an independent subscription library in Manchester, houses the papers for the Portico Prize. Established by the library in 1985, the Portico Prize has a history of recognising both fiction and non-fiction which depicts first the North West of England and latterly the broader North. The Northernness being judged is that represented rather than that of the creator. ${ }^{17}$ In the Portico archives, a letter from one of the Portico Prize's judging committee in 1993 was hesitant about potential comparisons to the Constable Trophy. Whilst both prizes deal with a sense of Northernness, they do so in differing ways. The letter is a reflective acknowledgement that prizes are seldom freestanding and instead make meaning in a relational sense. The Portico prize fosters Northern literary culture

\footnotetext{
${ }^{15}$ Constable \& Robinson were bought by Little, Brown Book Group in 2014. The name Constable is still in use as a publishing imprint. Tim Whiting, current head of Piatkus Constable Robinson Publishing Division at Little, Brown assisted in research for this article but confirmed that no archival holdings relating to the Trophy remain with Little, Brown.

16 A longlist of seventeen titles was announced in September 2019 spanning fiction, graphic memoir, social history, poetry, nature writing and autobiography.

${ }^{17}$ The geography of the Portico Prize evolved from an original focus on a narrowly defined North-West area (minus Cumbria) to a more capacious North from Scottish Border to a line across from Merseyside via the High Peak of Derbyshire to the Humber.
} 


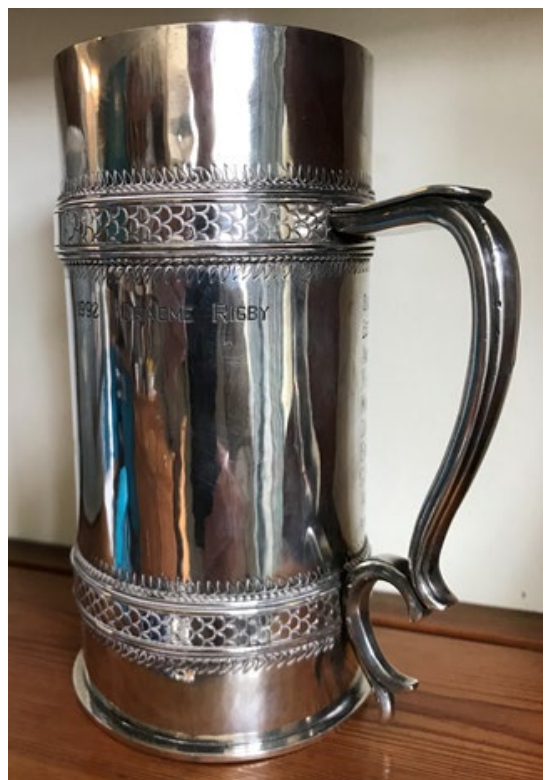

(a)

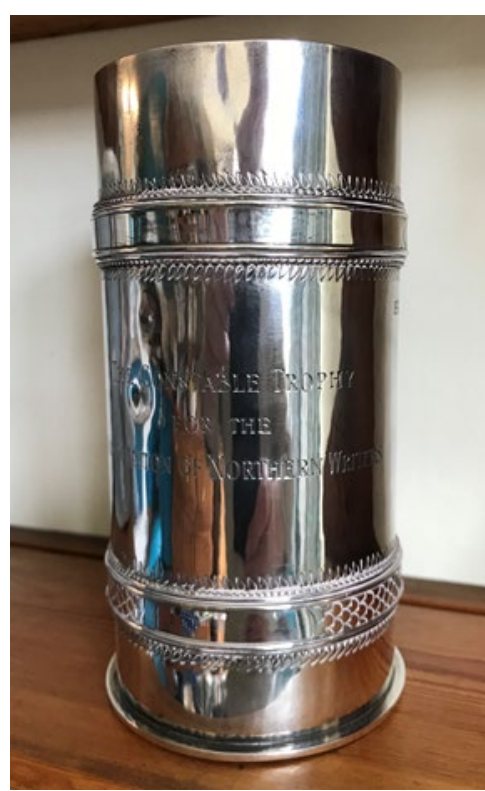

(b)

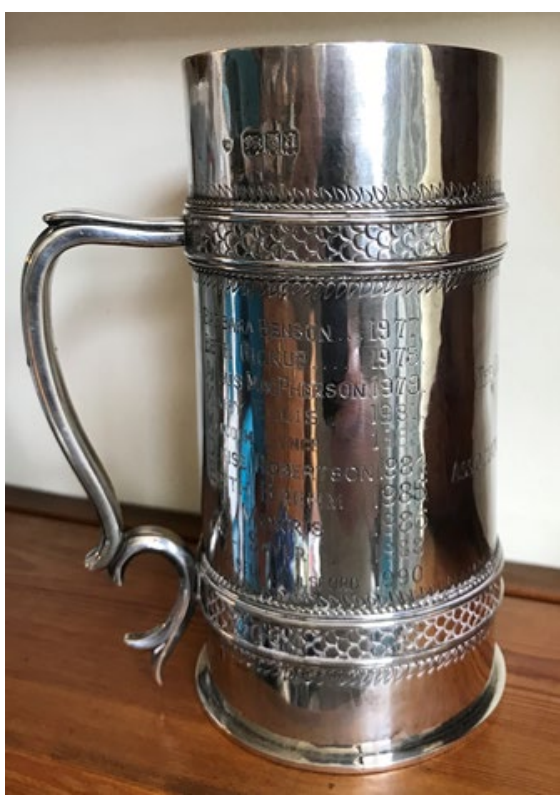

(c)

Figure 1. The Constable Trophy. (Left to Right) a) Front on Graeme's Name. b) Front on 'The Constable Trophy for the Association of Northern Writers' c) Front on main list of names.

and so shares a broad remit with the Constable. The Portico judge supplies a biographical note which mentions connection to the Constable Trophy but queries recognition and implicitly prestige:

Here's the paragraph you requested. I wasn't sure whether the Constable needed further explication - ie ('for a novel from the North West')? (ie. Has anybody heard of it?!!!). (emph. Original) (Judge's Letter, 1993)

The explication the judge provides in this letter is not accurate, conflating as it does the Portico's long focus on the North West with the Constable's longstanding focus on the North as a whole. This sets the question of knowledge of the prize in a rather different light. If someone who judged the Constable Trophy in 1988 was unaware of its geographic coverage by 1993, what hope might there be for a broader populace?

The Portico is important to reference here given that, established as an annual event in 1985, it quickly draws local media attention, partnering with BBC North West, Granada and the Manchester Evening News in its early years. The Portico's wealth of information in the archive demonstrates the administration and labour in establishing its own authority, and the solution it offers to questions of Northern literary recognition. The Portico's own founding document highlights how this is tied to the prize environment of the period:

There are already some 140 Literary Prizes, Grants and Awards in the UK ranging from f,50 and an engraved goblet to the $f_{15,000}$ Booker McConnell Prize. However, few of these are for books on specific regions, and not one covers the North-West excluding Cumbria, although the North-East is well represented (Portico Press Release, 1985). ${ }^{18}$

The language mirrors the assessments made by the Booker prize in its own founding press release in 1968:

There are already almost fifty literary prizes and awards available in this country, ranging from inscribed quills to sums of $f_{1}, 000$, for almost every conceivable type of literary work and category of author (ctd. in Squires, 2013: 295).

The imitation is deliberate. In planning and in process, the aim of the Portico was to define itself against the Booker, often seeking to cast itself as the 'Northern Booker' or 'Booker of the North'. A 1992 press release was widely reprinted which cast this comparison firmly as an alternative name 'The Portico Prize (The Northern Booker) was founded...', and later iterations of the prize repeat this naming (Portico Press Release, 1992).

The Portico's recognition that North-East literary work was being supported is a clear hint towards the range of schemes and awards that Northern Arts were offering in the region, alongside their administration of the Constable Trophy. Any direct coverage comparison becomes complicated by the incomparable nature of the prize

\footnotetext{
18 The goblet alluded to here is The Katharine Briggs Folklore Award given annually by the Folklore Society for the best book on folklore, established in 1982. The Cumbrian awards implied are Hunter Davies' Lakeland Book Awards which were established in 1984.
} 
environment. There are differences in the stage in the publishing cycle where each intervenes (pre-publication vs. post-publication), and contrasting priorities in Northern residency or Northern content. Yet, broadly, the Portico can be seen to respond to the same problem which the Constable was seeking to address, namely representing the North in a London-centric literary world. The Portico's evolution into a biennial award in 1993, and the more recent turn to working with the Arts Council are also steps which bring it closer to the precedent of the Constable Trophy.

In 2001, the Northern Rock Foundation, the grant-making charity formed when Northern Rock Building Society demutualised and floated on the stock exchange as a Bank in 1997, created the Northern Rock Foundation Writers' Award. This award had the aim of 'nurturing and developing writing talent in the north-east of England' (BBC News, 2003). The prize bestowed $f_{6} 60,000$ on one writer over three years, and also, in a biographic note of its inaugural winner Anne Stevenson, laid claim to the title of 'Northern Booker' (Page, 2003: 242). Most recently the name of the second winner of the Northern Rock Foundation Award, Julia Darling, has become attached, posthumously, to the Julia Darling Travel Fellowship, one of a suite of awards administered by the Northern writing agency, New Writing North. In operation since 1996, New Writing North have run the Northern Writers' Awards (NWAs) 'to help regional writers from the North access the national networks of UK publishing' (Shaw, 2018: 9). Katy Shaw offers a compelling case study of how the NWAs have helped support the regional literary economy. Shaw points out how 'historically, Northern writers have been forced to relocate to London and leave the region in order to achieve recognition or success in the UK literary industry. The NWAs address this problem by aiming to improve the economy of the North' (2018: 10). This should be qualified slightly, as the NWAs have only recently embraced a broader definition of the North, focusing primarily on the North-East from 1996 up until 2012 when a new funding settlement with Arts Council England widened to the North. Shaw goes on to suggest that the impact of the NWAs 'offers a vital new model of intervention and social value for the contemporary creative industries' (2018: 12). However, given that the aim of the NWAs since 2012 seems to directly replicate the aim of the Constable Trophy in its years of operation, it might be worthwhile seeing this model of intervention as pre-existing. Recalling the work literature officer Jenny Attala hinted that Northern Arts was undertaking, partnering with publishers and producers in the 1980s and 1990s, and considering that many successful alumni of the Trophy maintained Northern residency whilst going on to write more nationally published work, it would seem the NWAs are re-discovering a prior model.

The Constable Trophy worked across the broader geographic North for fifteen years and in that time the winners etched on the trophy, and those runners up who maintain a written connection in biographic notes, represent an interruption in the continuity of London-dominated literary work. Just as Childress et. al. have suggested that works entered for a prize might reveal 'a meaningful social space' (2017: 51), establishing a discontinuity that might 'act as a "first cut" into the continuity of objects' (2017: 51), entrants, runners-up and winners of the Trophy share the disruption of both the prize environment and the geographic bent of the publishing industry. Considering The Constable Trophy as a forerunner to the Portico Prize, the Northern Rock Writers' Award and the NWAs, it can be seen that working in tandem with public funding, each subsequent award moves closer to the same social space which seeks to uplift Northern writing. In this way, 'the processual nature of consecration' (Childress et. al, 2017: 51), is not simply about one award's internal sifting of entrants, but can expand to recognise both the gradual establishment of authority of the prize itself but also nested groups who have sought to disrupt the prize environment operating under similar notions of authority and solution.

One example of this continuity could be seen in the establishment of New Writing North, with the prior Constable Trophy judge, Pat Barker, as one of the agency's founding patrons. Another example might be the 2006 award of a NWA for 'Time to Write' to Barbara Gamble. Gamble, a runner up in the 1984 Constable Trophy had two novels published by Constable in total, and yet as New Writing North's director Claire Malcolm admitted on awarding the $f_{1} 10,000$, 'We met Barbara for the first time yesterday. She hadn't been on our radar at all' (The Journal, 2006). A parallel report mentioned that Gamble's first novel 'won $£ 1,000$ in a northern writers' competition, but didn't make any money in sales' (Teeside Live, 2006). In many responses to Gamble's NWA the lack of cultural memory or the dominance of organising powers in the prize environment seem to omit the fragile network established by the Trophy. Crucial to this is the absence of naming. The differentiation between 'a northern writers' competition' and the Trophy is the particularity of a named award, the Constable Trophy, amidst a sense that there are masses of indiscernible awards.

More recently, in its first year, the Northern Book Prize partnered with New Writing North and was awarded as one of the NWAs. The publication of Amy Arnold's Slip of a Fish in the Autumn of 2018 with And Other Stories ensures the start of a new Northern publication legacy. In 2019, the Northern Book Prize changed criteria, looking beyond Northern residency to admit the possibility of 'a writer who has a strong connection to the North' (And Other Stories, 2019). Likely due to this contradiction with the Arts Council definition of region, the Prize was not run with New Writing North. In 2019, judges Sarah Moss, Fiona Elmet and Stefan Tobler shortlisted titles internally but chose not to award a prize. A statement on the And Other Stories website makes clear that the 
publisher 'are in the process of signing contracts with authors who entered this year' underscoring the potential value of the prize, despite there being no conventional winner. Amongst the new awards in the 2019 NWAs, The NorthBound Book Award, supported by UCLan Publishing and Manchester-based publisher Saraband has been founded to recognise unpublished 'fiction or narrative non-fiction' for writers resident in the North of England (Lowes, 2018). ${ }^{19}$ The award promises money and guarantees of publication with Saraband. Considering this new prize alongside indications that the Northern Book Prize will run again in 2020, the cumulative work in recognising new Northern writing is growing.

\section{CONCLUSION}

Precision in reference to a history of Northern writing prizes begins to draw together common work, and recognises how the history of The Constable Trophy alongside the Portico Prize, the Northern Rock Writers' Award, the NWAs, the Northern Book Prize and The NorthBound Book Award provides a stronger answer to the shared cultural question asked by all - how do we address geographic under-representation in the literary industry? Recent work undertaken by Shaw has fed into national consultation on 'new policy formation, including the use of regional literary awards as a potential model of intervention for addressing regional under-representation in the UK literary industries and publishing' (Northumbria University, 2019). Such consultations are only as strong as their evidence base. Admitting the nuanced and particular history of regional literary awards in the North of England to this debate, by recognising the work of the Constable Trophy in the prize environment, would give a deeper understanding of those moments when a variety of cultural bodies have sought to address regional underrepresentation. Building critical histories of book prizes contributes to a more nuanced understanding of the history behind underrepresentation and imbalance in the book trade, and those strategies sought as redress. Recovering the cultural memory of awards ensures that important developments at the macro level of cultural strategy and the micro level of awards administration are highlighted, not least here the Trophy's navigation of a private-public partnership between the private publisher Constable and the RAAs that invest public monies in literature development. The impact the Trophy has had on creative careers cannot be deemed negligible. Tracing the experiences of past winners of the Constable Trophy, it became clear that some felt they had little or nothing notable to add to research when the opposite was true. Short-term views of public and private arts initiatives mean that recollections of winner experiences are a vital source to account for a longer involvement in answering longstanding inequities. The histories of dormant awards may appear unfashionable or un-newsworthy but hold important information on the prize environment they inhabited, and information for active prizes that constantly make decisions on how best to redirect cultural and economic capital. Understanding the legacy of the Constable Trophy, and accommodating strategic collegiality amidst the prize environment should enable wider legibility of each prize's cultural authority and amplify common efforts towards 'redistributive justice.'

\section{REFERENCES}

And Other Stories. (2019). Northern Book Prize. Available at: https://www.andotherstories.org/about-us/ northern-book-prize/ (Accessed 16 April 2019).

Anthony, P. (1974). Help For Writers, Newcastle Journal, 31 July, p. 7.

ArtsPack: The Magazine of the Mid-Pennine Association for the Arts. (1978) Jan/March. Available at: http://midpenninearts.org.uk/wp-content/uploads/2016/06/Prog-Jan-to-Mar-78.pdf (Accessed 16 April 2019).

BBC News (2003). 'Adventurous' writer wins literary prize. 11 March. Available at: http:// news.bbc.co.uk/1/hi/ england/2841423.stm (Accessed 16 April 2019).

Benson, B. (1977). The Underlings. London: Constable.

Best, J. (2008). Prize Proliferation. Sociological Forum, 23(1), 1-27. https:/ / doi.org/10.1111/j.1573-7861.2007. 00056.x

Binyon. T. J. (1993). Graeme Rigby. The Times Literary Supplement, 29 January, p. 21

Cameron, E. (2009). Obituary: Miles Huddleston, The Guardian. 12 February. Available at: https://www. theguardian.com/books/2009/feb/12/miles-huddleston-obituary (Accessed April 05, 2019).

Cassell's Directory of Publishing in Great Britain, the Commonwealth, Ireland, South Africa and Pakistan 1973-1974. (1973)

$7^{\text {th }}$ Edition. London: Cassell.

Casserley, M. (1988). Articulate Anxieties, The Times Literary Supplement, 28 October, p. 24.

${ }^{19}$ In 2019 the inaugural NorthBound Book Award was won by Juliana Mensah with an unpublished novel, Castles from Cobwebs. 
Childress, C., Rawlings, C. and Moeran, B. (2017). Publishers, authors, and texts: The Process of Cultural Consecration in Prize Evaluation Poetics 60, 48-61. https:/ / doi.org/10.1016/j.poetic.2016.10.001

Daily Mail. (1989). Rushdie Pipped at the Post. 25 January. p. 25.

de Jongh, N. (1989). Rushdie pipped to prize by nurse, The Guardian. 25 January, p. 1.

English, J. (2005). The Economy of Prestige. Cambridge, MA: Harvard University Press.

Ferrara, M. H. (1997). Writers Directory 1996-1998. London: St. James Press.

Fiction. (1985). Last Word. 4.4 Aug/Sep, p. 56.

Goodwin, J. (1990). Unscheduled Appearances, The Times Literary Supplement, 31 August, p. 916.

Isaacs, D. (1983). Novel Chance For Writers, Newcastle Journal. 10 October, p. 10.

Isaacs, D. (1985). Constable Trophy. Newcastle Journal, 20 December, p. 6.

Jones, T. (1989). The Constable Trophy, Newcastle Journal, 14 February, p. 3.

Judge's Letter. (1993). 1993 Folder, Portico Prize Archive. Manchester: The Portico Library.

Lowes, J. (2018). Northern Writers' Awards 2019 open with f,55,000 for writers. New Writing North. 15 November. Available at: http:// newwritingnorth.com/news/northern-writers-awards-2019-open-with55000-for-writers/ (Accessed 16 April 2019).

McGuigan, J. (1981). Writers and the Arts Council. London: Arts Council of Great Britain.

Menkes, V. (1989). Constable \& Company: Doing Well By Authors. British Book News July, 464-467.

Milne, K. (1987). Born to Raise Hell, The Guardian. 5 July, p. 20.

Mortimer, P. (1977). Barbara Makes a Late Break, Newcastle Journal, 14 October, p. 10.

Morton, B. (1989). A Case Against Society. The Times. 19 August. p. 31.

Nicholson, J. (1990). Papists, prods, tartan terrors, The Times. 24 May, p. 17. https://doi.org/10.1177/ 0038038590024001018

Northumbria University. (2019). Literature expert addresses House of Commons inquiry. 10 May. Available at: https://www.northumbria.ac.uk/about-us/news-events/news/katy-shaw-house-of-common-inquiry/ (Accessed 28 June 2019).

Page, R. (2003). Hyphen: An Anthology of Short Stories by Poets. Manchester: Comma Press.

Portico Press Release. (1985). Publicity/Press Releases, Portico Prize Archive. Manchester: The Portico Library.

Portico Press Release. (1992). Publicity/Press Releases, Portico Prize Archive. Manchester: The Portico Library.

Preston, P. (1987). Prizes and imprimaturs, The Listener, 17 September, p. 26.

Pulsford, P. (1990). Lee's Ghost. London: Constable.

Rittner, L. (1989). Secretary General's Report, in The Arts Council, Annual Report 1988-89 (pp. 4-5). London: Arts Council. Available at: https://www.artscouncil.org.uk/sites/default/files/download-file/Arts\%20 Council\%20-\%2044th\%20annual\%20report\%20and\%20accounts\%2088\%2089.pdf. (Accessed 16 April 2019).

Robertson, D. (2006). Diana, Me and the Male Stripper (Aged Two), Daily Mail 5 October. Available at: https://www.dailymail.co.uk/femail/article-408699/Diana-male-stripper--aged-two.html (Accessed 16 April 2019).

Shakespeare, N. (1985). Old people still have feelings, The Times. 27 June, p. 11.

Shaw, K. (2019). Writing the Northern Powerhouse: Evaluating the Northern Writers' Awards as a potential model of intervention for addressing regional representation in the 'London-Centric' UK literary industry, Creative Industries Journal 12(1), 3-13. https:/ / doi.org/10.1080/17510694.2018.1523667

Sherwood, J. (1993). Graeme's not so green now!, Newcastle Journal, 26 January, p. 33.

Southwell, A. (1984). A First Success, Newcastle Journal, 29 November, p. 8.

Squires, C. (2013). Literary Prizes and Awards, in G. Harper, (ed.) A Companion to Creative Writing (pp. 291-304). Oxford: Wiley-Blackwell. https://doi.org/10.1002/9781118325759.ch19

Squires, C. (2007). Marketing Literature: The Making of Contemporary Writing in Britain. Basingstoke: Palgrave Macmillan.

Stand. (1986). Constable Advert. 27.4, Autumn, p. 19. https:// doi.org/10.1016/0024-6301(86)90128-7

Street, J. (2005). 'Showbusiness of a Serious Kind': A Cultural Politics of the Arts Prize. Media, Culture \& Society, 27(6), 819-840. https://doi.org/10.1177/0163443705057672

Sutherland, J. (1978). Fiction and the Fiction Industry. London: The Athlone Press.

Sutherland, J. (1992). On the Salieri Express, London Review of Books. 14 (18) 24 September, pp. 18-20. Available at: https://www.lrb.co.uk/v14/n18/john-sutherland/on-the-salieri-express (Accessed 16 April 2019).

Taylor, D. J. (2005). Key to the Sardine Can, The Guardian, 30 April. Available at: https://www.theguardian.com/ books/2005/apr/30/featuresreviews.guardianreview7 (Accessed 16 April 2019).

Teeside Live. (2006). Writer Barbara follows her Star. 21 April. Available at: https://www.gazettelive.co.uk/ news/ local-news/writer-barbara-follows-her-star-3776009 (Accessed 16 April 2019). 
The Chair. (1978). 7. Available at: http:// poetrymagazines.org.uk/magazine/recordf97a.html?id=30557 (Accessed 16 April 2019).

The Journal. (2006). Great Gamble proves to be a winner at awards. 11 April. Available at: http://www. thejournal.co.uk/news/north-east-news/great-gamble-proves-winner-awards-4576828 (Accessed 16 April 2019).

The Man Booker Prize. (2018). BBC Documentary on 50 Years of the Man Booker Prize to Air on Eve of 2018 Ceremony. Available at: https://www.themanbookerprize.com/resources/media/pressreleases/bbcdocumentary-50-years-man-booker-prize-air-eve-2018-ceremony (Accessed 16 April 2019).

The Spectator. (1985). New Fiction from Constable. 254.8189, June 22, p. 25.

The Times. (1993). Radio Guide. 2 February, p. 39.

Vidal, J. (1989). Echoes in a Silent World, The Guardian. 26 January, p. 24.

Wasserman, P. and Mclean, J. W. (1982). Awards, Honors and Prizes, Volume 2: International and Foreign. $5^{\text {th }}$ Edition. Detroit: Gale.

Wecksler, S. (1980). International Literary Market Place 1980. New York and London: R.R. Bowker Company, 1980.

Wood, H. (2017). And Other Stories Launches $£ 5 \mathrm{k}$ Northern Book Prize. The Bookseller. September 21. Available at: https://www.thebookseller.com/news/and-other-stories-launches-5k-northern-book-prize-celebratesheffield-move-642416 (Accessed April 05, 2019).

Young, R. (1989). First-timer carries off the Whitbread Prize, The Times. 25 January, p. 1. 